\title{
THE ORGANIC FERTILIZERS RESIDUAL AND EARTHWORM INTRODUCTION ON GROWTH AND YIELD OF UPLAND RICE
}

\author{
Dick Dick Maulana ${ }^{1 *}$, Suli Suswana ${ }^{2}$ \\ ${ }_{1,2}$ Agricultural Faculty of Islamic Nusantara University \\ Author contact: dickdick.maulana@yahoo.com
}

\begin{abstract}
S
In modern agriculture, over use of inorganik fertilizers causes dangerous effects on environment, human health and loss of soil fertility. Soil organic matter is a main indicator of the quality and healthy soils. Organic matter mineralization is a key process that releasing the available nutrients to the plants. There are many organisms involved in the mineralization processes. Earthworm enable to digest soil organik matters, and the excretion's have more available nutrients content, that potential to increase nutrients absorption. This research intended to study influences of organic fertilizers residuals and earthworm introduction on growth of the upland rice in pots. The experiment was conducted in Agricultural Faculty of Universitas Islam Nusantara (UNINUS), from January - June 2017, with RBD that comprised of two factors: (1) earthworm; and (2) residual of kinds and rates of the organik fertilizers. The results showed that aren't significantly interaction influences of the organik fertilizers residuals and earthworm introduction on growth and yield of upland rice also to increase yield components of upland rice.
\end{abstract}

Keywords: Organic Fertilizer Residuals, Earthworm, Soil Quality, Upland Rice

Maulana DD, Suswana S. 2018. Pengaruh residu pupuk organik dan cacing tanah terhadap pertumbuhan dan hasil padi gogo. Agrotech Res J 2(2): 63-68.

Maulana DD, Suswana S. 2018. The organic fertilizers residual and earthworm introduction on growth and yield of upland rice. Agrotech Res J 2(2): 63-68.

\section{PENDAHULUAN}

Pada pertanian modern seperti saat ini, penggunaan pupuk anorganik yang berlebihan berdampak kepada kondisi lingkungan, kesehatan manusia dan kesuburan tanah. Secara umum pemanfaatan pupuk kimia dapat meningkatkan produksi, namun penggunaan secara berlebihan dapat mengeraskan tanah, menurunkan kesuburan, meningkatkan penggunaan pestisida, mencemari air dan udara, mengakibatkaan efek rumah kaca, sehingga akhirnya berdampak pada kesehatan manusia dan lingkungan secara keseluruhan (Shanika, 2015). Penurunan kesuburan tanah merupakan kerusakan fungsi dari faktor penopang tanaman dalam kemampuannya mengubah hara menjadi bentuk yang dapat dimanfaatkan oleh tanaman (Notohadikusuma, 1999). Pada tingkat paling ekstrim, yakni pada aras pemberian pupuk kimia tidak dapat menopang secara berkelanjutan hara yang hilang dari dalam tanah dan juga bahan-bahan penyehat tanah.

Perbandingan antara unsur hara terserap dalam tanah dan hara yang diberikan (recovery efficiency) merupakan permasalahan utama jumlah pupuk yang sesuai dengan kebutuhan tanaman. Efisiensi tersebut merupakan bagian penting dari keseluruhan faktor eksternal tanaman (seperti tekstur tanah, $\mathrm{pH}$ tanah, iklim, cara pengelolaan, jenis pupuk dan implementasinya) dan juga faktor internal pada tanaman (pola pertumbuhan, pola perakaran, kesehatan tanaman, dan besar kebutuhan hara tanaman pada setiap fase tumbuh).

IImuan dan peneliti sering beradu pendapat tentang pemanfaatan berbagai jenis pupuk organik yang dapat digunakan untuk meningkatkan ketersediaan unsur hara, retensi unsur hara dan penanganan pencemaran

${ }^{*}$ Fak. Pertanian Universitas Islam Nusantara Jl. Soekarno-Hatta 530, Buah Batu, Bandung tanah dan di sisi lain lebih mengenai penanganannya terhadap lingkungan dan kehirupan dari pemanfaatan berlebihan dari pupuk kimia.

Indonesia merupakan negara yang mengandalkan pertanian sebagai salah satu indikator pertumbuhan ekonomi. Oleh karena itu, produksi pertanian di Indonesia setiap tahun harus dalam kondisi yang terpenuhi dan diharapkan mengalami peningkatan untuk mengimbangi pertumbuhan penduduknya seiring fluktuasi dimana pemanfaatan lahan pertanian. Bermula dari tahun 1990, para ahli mulai mempertanyakan keberlanjutan strategi intensifikasi "revolusi hijau" dalam hal pelambatan pertumbuhan hasil dan degradasi lahan (Burno and Ladha, 2009). Pelambatan tersebut terjadi akibat dari degradasi lahan di kawasan pertanian khususnya terjadi pada tanaman-tanaman strategis seperti padi di kawasan pantura dan karawang. Beras merupakan bahan pangan pokok bagi 95\% penduduk Indonesia (Swastika et al., 2007).

Adopsi padi produksi tinggi dan berumur pendek saat revolusi hijau semakin luas. Perbaikan pengelolaan tanaman, ketersediaan irigasi, dan penggunaan bahan kimia selama revolusi hijau telah membawa ke arah intensifikasi cepat di lahan sawah daerah tropika di Asia. Hal itu berakibat pada beban terhadap tanah dan sumberdaya alam lain semakin besar (Suswana, 2015).

Produksi padi rata-rata Indonesia pada tahun 2013 sebesar 71,3 juta ton, padi sawah 67,4 juta ton, dan padi ladang 3,9 juta ton; dengan produktivitas padi rata-rata 5,2 ton/ha, padi sawah 5,3 ton/ha, dan padi ladang 3,3 ton/ha (Basis Data Statistik Pertanian, 2015). Produktivitas padi pada lahan bukan sawah (tadah hujan dan gogo) masih rendah antara lain disebabkan oleh kendala lingkungan biofisik yang belum terpecahkan (Makarim, 2009). Masalah lingkungan biofisik terutama di lahan sawah perlu 
menjadi fokus perhatian terutama dalam hal peningkatan kualitas udara dan air di dalam tanah dalam rangka mempertahankan kondisi tanah dalam menopang ketersediaan unsur hara.

Dengan abad ke-20 yang telah berlalu, perhatian terhadap kualitas udara dan air menjadi sama penting dengan perhatian terhadap produktivitas pertanian (Bellows, 2005). Untuk menuju ke arah perlindungan lingkungan dan memelihara potensi produksi lahan, sekarang ini upaya-upaya yang dilakukan harus lebih meningkatkan upaya pengendalian dan pengelolaan dampak erosi untuk dapat meningkatkan kualitas tanah. Cara yang paling praktis untuk meningkatkan kualitas tanah adalah melalui gerakan pengelolaan bahan organik atau $\mathrm{C}$ tanah. Banyak sifat-sifat tanah mempengaruhi kualitas tanah, tetapi disisi lainbahan organik sebaiknya mendapat perhatian khusus. Bahtan organik mempengaruhi beberapa fungsi tanah yang bersifat kritis, dapat dimanipulasi melalui praktek pengelolaan lahan, dan penting dalam kebanyakan kondisi pertanian. Tambahan pula bahwa peningkatan kadar bahan organik tanah dapat mengurangi kadar $\mathrm{CO}_{2}$ atmosfer yang berkontribusi terhadap perubahan iklim (Bellows, 2005).

Peningkatan ketersediaan bahan organik tanah berakibat pada: kualitas udara, air, dan produktivitas pertanian membaik, dicirikan dengan debu, alergen, dan pathogen di udara segera menurun; muatan sedimen dan unsur hara dalam air permukaan menurun segera setelah agregasi tanah meningkat dan aliran permukaan menurun; kualitas air bawah tanah dan air permukaan membaik karena struktur, infiltrasi dan kapasitas menahan air lebih baik, dan aktivitas biologik membuat tanah menjadi suatu filter yang lebih efektif, serta kemampuan tanaman untuk bertahan dari kekeringan lebih baik apabila infiltrasi dan kapasitas menahan air tanah meningkat. Bahan organik dapat membalut pestisida, sehingga menjadi kurang aktif. Bahan organik dapat menekan organisme pengganggu tanaman sehingga mengurangi kebutuhan akan pestisida. Kesehatan dan vigor tanaman meningkat apabila aktivitas dan diversitas biota tanah meningkat. Habitat satwa membaik apabila pengelolaan residu tanaman membaik (Bellows, 2005).

Cacing tanah merupakan organisme tanah penting yang mempengaruhi banyak sifat-sifat tanah penting, seperti pembentukan agregat tanah, kapasitas menahan air, aktivitas mikroflora melalui pencampuran sisa-sisa tanaman dan tanah mineral, dan ketersediaan unsur hara. Oleh karena pengaruh terhadap sifat-sifat tanah itu, cacing tanah kerap berpengaruh terhadap pertumbuhan tanaman (Roubickova et al., 2009). Dari hasil penelitian laboratorium Roubickova et al. (2009), cacing tanah secara nyata meningkatkan biomassa Festuca rubra dan Trifolium hibridum. Peningkatan biomassa itu sesuai dengan penurunan $\mathrm{pH}$ yang nyata dan peningkatan $\mathrm{C}$ teroksidasi, $\mathrm{N}$-total, kandungan $\mathrm{P}, \mathrm{K}$ dan $\mathrm{Ca}$ dapat dipertukarkan.

Hasil penelitian Kaviraj, et al. (2003) menunjukkan bahwa hasil analisis kimia kotoran cacing tanah memiliki jumlah magnesium, nitrogen dan potassium lebih tinggi dibandingkan dengan tanah di sekitarnya. Selain itu, hasil analisis oleh Badan Penelitian dan Pengembangan Pertanian (2008), menunjukkan bahwa bahan organik yang telah terdekomposisi oleh cacing tanah, mempunyai sifat kimia lebih unggul, yaitu memiliki kandungan $\mathrm{N}$ dan $\mathrm{P}$ tinggi. Kandungan $\mathrm{N}$ tinggi berasal dari perombakan bahan organik kaya $\mathrm{N}$ dan ekskresi mikroba yang bercampur dengan tanah dalam sistem percernaan cacing tanah.

Berdasarkan uraian di atas tergambarkan bahwa permasalahan utama penurunan peningkatan produktivitas dan efisiensi produksi padi adalah karena penurunan kandungan bahan organik tanah. Karama (2000) melaporkan bahwa pada tahun 1999 tercatat luas tanah sawah di pulau Jawa dan di lumbung pangan di luar Jawa yang mengandung bahan organikkurang dari $1 \%$ telah mencapai $80 \%$. Namun upaya pemulihan kualitas tanah melalui penambahan pupuk organik sering terlambat memberikan pengaruh positif. Ini karena proses mineralisasi pupuk organik berjalan lambat, sehingga pengaruh terhadap pertumbuhan tanaman tidak signifikan pada musim tanam pertama. Hasil penelitian lapangan Danuwikarsa et al. (2012) menunjukkan bahwa pemberian pupuk kotoran sapi tidak berpengaruh secara signifikans, baik terhadap pertumbuhan maupun komponen hasil padi sawah. Hasil penelitian pada musim sebelumnya menunjukkan bahwa introduksi cacing tanah tidak signifikan mempengaruhi pertumbuhan padi gogo. Pemberian pupuk kandang ayam broiler 5 ton/ha mampu meningkatkan tinggi tanaman dan jumlah anakan, serta cenderung mempercepat keluar malai, meningkatkan jumlah malai per rumpun, jumlah bulir per malai, jumlah bulir bernas per malai, dan hasil gabah kering panen per rumpun. Pemberian pupuk kandang ayam broiler juga berpengaruh lebih baik terhadap pertumbuhan dan komponen hasil padi gogo bila dibandingkan dengan pemberian pupuk petroganik 5 dan 10 ton/ha (Suswana, 2015).

Penelitian bertujuan untuk menguji pengaruh residu pupuk kandang broiler pemberian musim tanam sebelumnya dan aktivitas cacing tanah (Lumbricus rubellus Hoffm.) terhadap pertumbuhan dan hasil padi gogo varietas Situbagendit.

\section{BAHAN DAN METODE}

Penelitian melalui percobaan di Lahan Percobaan Fakultas Pertanian UNINUS, Jawa Barat, Indonesia (posisi geografi $107^{\circ} 7^{\prime \prime} 45^{\prime}$ LS dan $6^{\circ} 3$ "57' BT) pada bulan Januari sampai dengan Juni 2017. Penelitian merupakan lanjutan penelitian musim tanam sebelumnya (panen pada November 2016).

Bahan yang digunakan dalam penelitian ini sama dengan yang digunakan pada musim sebelumnya, karena pada penelitian ini tidak diaplikasikan perlakuan baru. Bahan yang digunakan pada musim sebelumnya meliputi tanah mineral, pupuk organik (kompos kotoran sapi, kompos kotoran kambing, pupuk kandang ayam pedaging (broiller litter), dan petroganik, dan benih 
padi gogo varietas Situbagendit, dan cacing tanah (Lumbricus rubellus Hoffm.). Alat-alat yang digunakan juga sama dengan yang digunakan pada musim sebelumnya, yakni meliputi pot plastik hitam, kertas label, emrat, timbangan, dan meteran.

Benih yang ditanam sebanyak 10 biji per pot pertumbuhannya tidak seragam, sehingga perlu dilakukan penyulaman untuk menyeragamkan jumlah tanaman seluruh satuan percobaan pada awal percobaan. Selama masa pertumbuhan tanaman terjadi serangan hama, diantaranya belalang, ulat, walangsangit, dan sejenis kutu pada akar. Selanjutnya hama tikus ditanggulangi dengan memasang pagar seng di sekeliling areal percobaan. Hama belalang, ulat, dan walangsangit diatasi dengan cara ditangkapi secara manual setiap hari. Gulma yang tumbuh dicabuti setiap hari, sehingga di dalam pot percobaan hanya ada tanaman padi saja.

Pengamatan yang dilakukan pada penelitian ini terdiri dari pengamatan utama dan pengamatan penunjang. Pengamatan utama adalah pengamatan terhadap variabel-variabel pertumbuhan tanaman, yaitu: tinggi tanaman, jumlah anakan, dan umur keluar malai. Pengamatan tinggi tanaman dan jumlah anakan dilakukan pada waktu tanaman berumur $8,10,12$, dan 14 minggu setelah tanam. Pengamatan komponen hasil meliputi jumlah malai per rumpun (jumlah anakan produktif), panjang malai, jumlah bulir per malai, dan bobot 100 butir gabah kering panen. Pengamatan penunjang menyangkut pengamatan terhadap performa pertumbuhan tanaman secara umum, seperti vigor tanaman, kasus-kasus gangguan hama/penyakit, dan lain-lain.

Analisis statistik dilakukan terhadap data variabel pertumbuhan tanaman sesuai dengan model linier RAK, dalam hal ini menggunakan uji $F$ (anova) 5\%, perlakuan yang berbeda nyata diuji lanjut dengan LSD $0,05 \%$.

\section{HASIL DAN PEMBAHASAN}

\section{Pengamatan penunjang}

Tanah pada awal penelitian musim tanam sebelumnya memiliki kandungan $\mathrm{C}$-organik sedang $(2,4 \%), \mathrm{N}$-total sangat rendah $(0,09 \%), \mathrm{C} / \mathrm{N}$ sangat tinggi (27), $\mathrm{P}_{2} \mathrm{O}_{5}$ total sangat rendah $(14 \mathrm{mg} / 100 \mathrm{~g})$, $\mathrm{P}$-tersedia sangat rendah (4 ppm), $\mathrm{K}_{2} \mathrm{O}$-total sangat rendah $(7,1 \mathrm{mg} / 100 \mathrm{~g})$, Kapasitas Tukar Kation (KTK) rendah $(5,14 \mathrm{me} / 100 \mathrm{~g})$, kejenuhan basa (KB) tinggi, kejenuhan aluminium tak terukur, kation-kation K-dd rendah, Ca-dd dan Mg-dd tinggi. Tanah sengaja tidak dianalisis kembali karena peneliti mencoba menguji pengaruh residu dari tanaman padi tersebut

\section{Tinggi tanaman}

Interaksi antara residu pupuk organik dan introduksi cacing tanah tidak terhadap tinggi tanaman pada $6,8,10$, dan 12 minggu setelah tanam (MST). Pengaruh mandiri dari perlakuan introduksi cacing tanah juga tidak signifikan (Tabel 1).
Tabel 1 Pengaruh residu cacing tanah dan pupuk organik terhadap tinggi tanaman pada 8, 10, 12 dan 14 MST

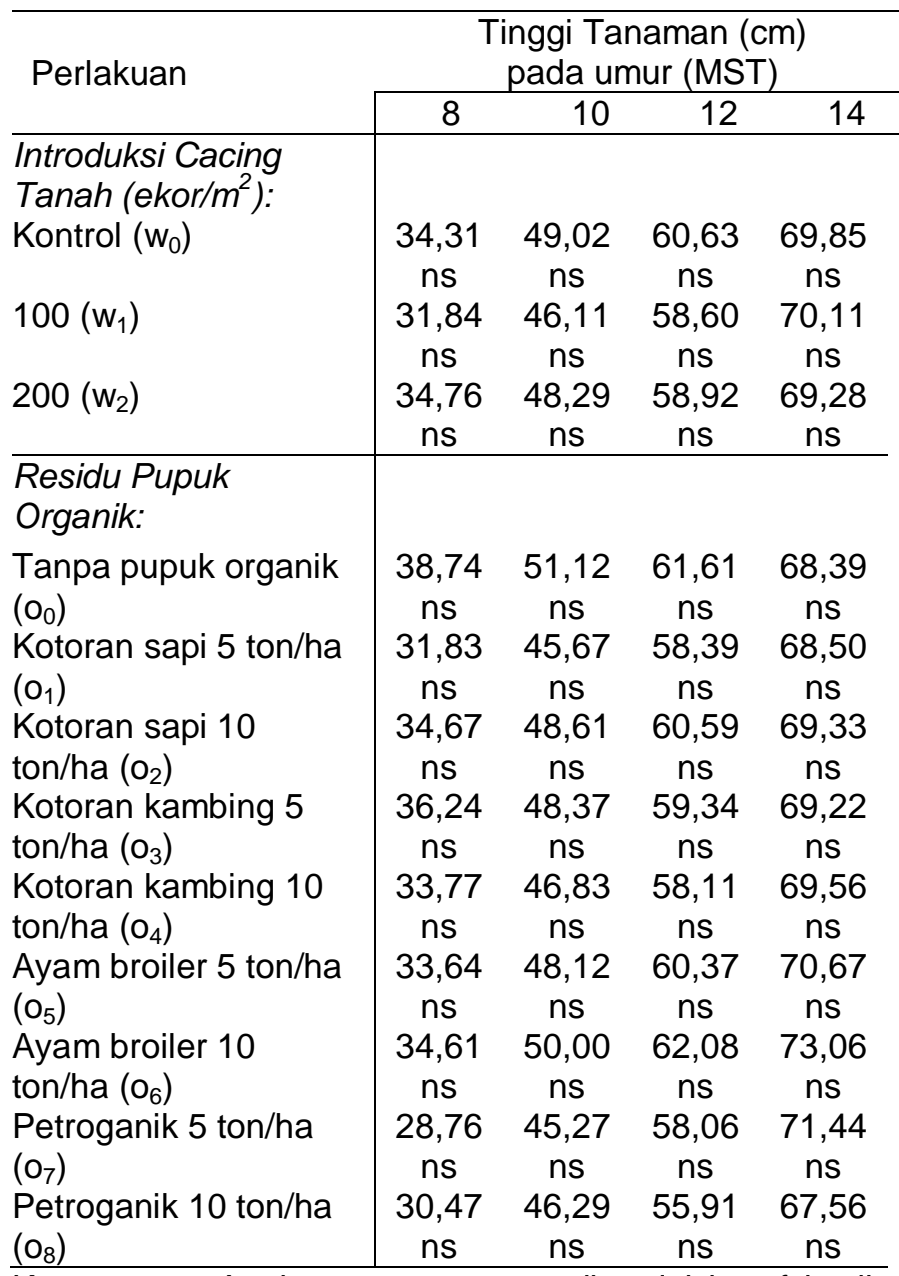

Keterangan: Angka rata-rata yang ditandai huruf kecil sama ke arah vertikal ns = non-signifikan berdasarkan uji LSD pada taraf nyata $5 \%$;

\section{Umur keluar malai}

Pengaruh interaksi dari sisa perlakuan populasi cacing tanah dan residu pupuk organik tidak signifikan terhadap umur keluar malai. Pengaruh mandiri dari introduksi cacing tanah juga tidak signifikan terhadap umur keluar malai. Begitu pula pengaruh mandiri dari perlakuan pupuk organik (Tabel 2).

Tabel 2 Pengaruh mandiri dari residu introduksi cacing tanah dan pupuk organik terhadap umur inisiasi malai

\begin{tabular}{lc}
\hline Perlakuan & $\begin{array}{c}\text { Umur Inisiasi } \\
\text { Malai (HST) }\end{array}$ \\
\hline Introduksi Cacing Tanah $\left(\mathrm{ekor} / \mathrm{m}^{2}\right):$ & \\
Kontrol $\left(\mathrm{w}_{0}\right)$ & $120,04 \mathrm{~ns}$ \\
$100\left(\mathrm{w}_{1}\right)$ & $123,00 \mathrm{~ns}$ \\
$200\left(\mathrm{w}_{2}\right)$ & $119,44 \mathrm{~ns}$ \\
\hline
\end{tabular}

Residu Pupuk Organik :

Tanpa pupuk organik $\left(\mathrm{o}_{0}\right)$

$120,44 \mathrm{~ns}$

Kotoran sapi 5 ton/ha $\left(\mathrm{O}_{1}\right)$ $123,00 \mathrm{~ns}$ $119,89 \mathrm{~ns}$ Kotoran sapi 10 ton/ha $\left(\mathrm{O}_{2}\right)$ $122,44 \mathrm{~ns}$ Kotoran kambing 5 ton/ha $\left(\mathrm{O}_{3}\right)$ Kotoran kambing 10 ton/ha $\left(\mathrm{O}_{4}\right)$
120,67 ns 


\begin{tabular}{lc}
\hline Perlakuan & $\begin{array}{c}\text { Umur Inisiasi } \\
\text { Malai }(\mathrm{HST})\end{array}$ \\
\hline Ayam broiler 5 ton/ha $\left(\mathrm{O}_{5}\right)$ & $119,78 \mathrm{~ns}$ \\
Ayam broiler 10 ton/ha $\left(\mathrm{O}_{6}\right)$ & $120,44 \mathrm{~ns}$ \\
Petroganik 5 ton/ha $\left(\mathrm{O}_{7}\right)$ & $120,67 \mathrm{~ns}$ \\
Petroganik 10 ton/ha $\left(\mathrm{O}_{8}\right)$ & $120,11 \mathrm{~ns}$ \\
\hline
\end{tabular}

Keterangan: Angka rata-rata yang ditandai huruf kecil sama ke arah vertikal, ns = non-signifikan berdasarkan uji LSD pada taraf nyata $5 \%$

\section{Jumlah malai per rumpun}

Pengaruh interaksi dari perlakuan cacing tanah dan pupuk organik tidak signifikan terhadap jumlah malai per rumpun dan panjang malai. Pengaruh mandiri dari introduksi cacing tanah juga tidak signifikan. Akan tetapi, pengaruh mandiri dari perlakuan pupuk organik signifikan baik terhadap jumlah malai per rumpun maupun panjang malai (Tabel 3).

Tabel 3 Pengaruh residual dari pupuk organik dan introduksi cacing tanah terhadap jumlah malai per rumpun (anakan produktif)

\begin{tabular}{lc}
\hline Perlakuan & $\begin{array}{c}\text { Jumlah Malai per } \\
\text { Rumpun }\end{array}$ \\
\hline Introduksi Cacing Tanah & \\
$\left(\right.$ ekor $\left./ \mathrm{m}^{2}\right):$ & \\
Kontrol $\left(\mathrm{w}_{0}\right)$ & $17,93 \mathrm{~ns}$ \\
$100\left(\mathrm{w}_{1}\right)$ & $16,48 \mathrm{~ns}$ \\
$200\left(\mathrm{w}_{2}\right)$ & $17,89 \mathrm{~ns}$ \\
\hline
\end{tabular}

Residu Pupuk Organik :

Tanpa pupuk organik $\left(\mathrm{O}_{0}\right)$

$18,22 \mathrm{~ns}$

Kotoran sapi 5 ton/ha $\left(\mathrm{O}_{1}\right)$

$16,22 \mathrm{~ns}$

Kotoran sapi 10 ton/ha $\left(\mathrm{O}_{2}\right)$

$16,56 \mathrm{~ns}$

Kotoran kambing 5 ton/ha

$\left(\mathrm{O}_{3}\right)$

$18,33 \mathrm{~ns}$

Kotoran kambing 10 ton/ha

$\left(\mathrm{O}_{4}\right)$

Ayam broiler 5 ton/ha $\left(\mathrm{O}_{5}\right)$

Ayam broiler 10 ton/ha $\left(\mathrm{O}_{6}\right)$

Petroganik 5 ton/ha $\left(\mathrm{O}_{7}\right)$

Petroganik 10 ton/ha $\left(\mathrm{O}_{8}\right)$

$18,00 \mathrm{~ns}$

19,22 ns

$18,44 \mathrm{~ns}$

$16,67 \mathrm{~ns}$

$15,22 \mathrm{~ns}$

Keterangan: Angka rata-rata yang ditandai huruf kecil sama ke arah vertikal ns = non-signifikan berdasarkan uji LSD pada taraf nyata $5 \%$

\section{Hasil gabah per rumpun}

Pengaruh interaksi dari perlakuan cacing tanah dan pupuk organik non signifikan terhadap hasil gabah kering panen (GKP) per rumpun. Pengaruh mandiri dari perlakuan introduksi cacing tanah juga non signifikan. Sedangkan pengaruh mandiri dari perlakuan pupuk organik signifikan (Tabel 4).

Tabel 4 Pengaruh residual dari pupuk organik dan introduksi cacing tanah terhadap hasil gabah per rumpun

\begin{tabular}{lc}
\hline \multicolumn{1}{c}{ Perlakuan } & $\begin{array}{c}\text { Hasil Gabah per Rumpun } \\
\text { (gram) }\end{array}$ \\
\hline $\begin{array}{l}\text { Introduksi Cacing Tanah } \\
\left(\text { ekor } / \mathrm{m}^{2}\right):\end{array}$ \\
Kontrol $\left(\mathrm{w}_{0}\right)$ & $20,32 \mathrm{~ns}$
\end{tabular}

\begin{tabular}{|c|c|}
\hline Perlakuan & $\begin{array}{c}\text { Hasil Gabah per Rumpun } \\
\text { (gram) }\end{array}$ \\
\hline $100\left(w_{1}\right)$ & $18,10 \mathrm{~ns}$ \\
\hline $200\left(w_{2}\right)$ & $20,10 \mathrm{~ns}$ \\
\hline Residu Pupuk Organik & \\
\hline Tanpa pupuk organik $\left(\mathrm{o}_{0}\right)$ & 18,18 ns \\
\hline Kotoran sapi 5 ton/ha $\left(\mathrm{O}_{1}\right)$ & $17,78 \mathrm{~ns}$ \\
\hline $\begin{array}{l}\text { Kotoran sapi } 10 \text { ton/ha } \\
\left(\mathrm{O}_{2}\right)\end{array}$ & $18,69 \mathrm{~ns}$ \\
\hline $\begin{array}{l}\text { Kotoran kambing } 5 \text { ton/ha } \\
\left(\mathrm{O}_{3}\right)\end{array}$ & $17,90 \mathrm{~ns}$ \\
\hline $\begin{array}{l}\text { Kotoran kambing } 10 \\
\text { ton/ha }\left(\mathrm{O}_{4}\right)\end{array}$ & 20,37 ns \\
\hline Ayam broiler 5 ton/ha $\left(\mathrm{O}_{5}\right)$ & 22,35 ns \\
\hline $\begin{array}{l}\text { Ayam broiler } 10 \text { ton/ha } \\
\left(\mathrm{O}_{6}\right)\end{array}$ & $22,81 \mathrm{~ns}$ \\
\hline Petroganik 5 ton/ha $\left(\mathrm{O}_{7}\right)$ & 21,13 ns \\
\hline Petroganik 10 ton/ha $\left(\mathrm{O}_{8}\right)$ & $16,35 \mathrm{~ns}$ \\
\hline
\end{tabular}

Keterangan: Angka rata-rata yang ditandai huruf kecil sama ke arah vertical ns = non-signifikan berdasarkan uji LSD pada taraf nyata $5 \%$

Hasil penelitian ini menunjukkan bahwa pengaruh introduksi cacing tanah secara konsisten tidak signifikan terhadap variable-variabel pertumbuhan dan hasil padi gogo. Hal ini dikarenakan pada penelitian sebelumnya pengaruh introduksi cacing tanah non signifikan terhadap berbagai variable pertumbuhan dan hasil padi gogo. Hal ini dikarenakan pada penelitian sebelumnya diketahui bahwa peran-peran penting cacing tanah yang diintroduksikan dalam suatu agroekosistem, seperti aktivitas makan, memperkuat dekomposisi bahan organik, pembentukan humus, mempercepat siklus unsur hara dan perkembangan struktural tanah cacing tanah juga meningkatkan kuantitas nitrogen termineralisasikan dari bahan organik tanah tersebut sebagian sudah dilakukan oleh koloni cacing tanah endogeneous (Kaviraj et. al. 2003). Diketahui sebelumnya bahwa tanah yang digunakan tidak dipastikan terbebas dari koloni cacing tanah; atau cacing tanah yang diintroduksikan belum beradaptasi dengan kondisi ekologinya yang baru di dalam pot sehingga belum beraktivitas secara efektif. Diketahui pula bahwa bakteri penambat-nitrogen terdapat di dalam perut cacing dan dalam kascing, aktivitas enzim nitrogenase lebih tinggi, yang berarti laju fiksasi nitrogen lebih besar dan ternyata pada penelitian ini belum cukup signifikan pengaruhnya terhadap pertumbuhan dan hasil padi gogo (Kaviraj et. al., 2003).

Hasil gabah kering panen dengan pupuk kandang ayam broiler 5 ton/ha $\left(\mathrm{O}_{5}\right)$ cenderung lebih tinggi (signifikan) jika dibandingkan dengan tanpa pupuk organik $\left(\mathrm{O}_{0}\right)$ dan signifikan bila dibandingkan pupuk petroganik 10 ton/ha $\left(\mathrm{O}_{8}\right)$ dan 5 ton/ha $\left(\mathrm{O}_{7}\right)$. Pengaruh dari pupuk kandang ayam broiler 5 ton/ha terhadap hasil gabah kering panen ini konsisten dengan pengaruhnya terhadap jumlah malai per rumpun, jumlah bulir per rumpun, dan jumlah bulir bernas per rumpun. Fakta ini menunjukkan bahwa jelas pupuk kandang ayam broiler lebih baik pengaruhnya terhadap komponen hasil padi gogo dibandingkan dengan jenis 
pupuk organik lainnya. Hal ini diduga karena komposisi kimiawi dari campuran sekam padi dan kotoran ayam broiler lebih cocok bagi pertumbuhan baik vegetatif maupun generatif tanaman padi gogo.

\section{KESIMPULAN DAN SARAN}

\section{Kesimpulan}

Residu dari pupuk kandang ayam broiler 5 ton/ha tidak mampu meningkatkan pertumbuhan tinggi tanaman dan jumlah anakan, serta keluarnya malai, jumlah malai per rumpun, dan tidak mempengaruhi hasil gabah kering panen per rumpun. Pemberian pupuk kandang ayam broiler tidak memberikan pengaruh terhadap pertumbuhan dan komponen hasil padi gogo varietas Situbagendit selaras dengan hasil residu pemberian pupuk petroganik 5 dan 10 ton/ha. Sejumlah residu pupuk organik pada agroekosistem dalam jangka waktu tertentu efektif memberikan pengaruh pada musim pertama saja, sedangkan pada musim tanam kedua sudah tidak efektif lagi, yang mana pengebabnya diduga sebagai akibat dari cepatnya proses dekomposisi bahan organik pada kondisi lahan padi gogo yang aerob dengan kelembaban yang cukup memadai. Hal ini menunjukkan bahwa pemberian pupuk organik untuk meningkatkan kondisi fisik, kimia, dan biologi tanah pada usaha tani padi gogo perlu dilakukan pada setiap awal musim tanam.

Introduksi cacing tanah non signifikan mempengaruhi pertumbuhan tanaman padi gogo varietas Stubagendit. Hal ini dikarenakan pengaruh introduksi cacing tanah pada penelitian sebelumnya diperoleh hasil yang konsiten non signifikan terhadap berbagai variable pertumbuhan dan hasil padi gogo.

\section{Saran}

Berdasarkan hasil penelitian diperoleh bahwa pemberian pupuk organik perlu dilakukan pada setiap awal musim tanam. Diperlukan pengujian pengaruh residual pupuk organik dan introduksi cacing tanah pada kondisi agroekosistem lahan kering yang sesungguhnya sehingga diperoleh data yang riil bagi petani.

\section{DAFTAR PUSTAKA}

Basis Data Statistik Pertanian. 2015. Statistik Pertanian Indonesia. http://aplikasi. deptan.go.id/bdsp/hasil_kom. asp.

Bellows, B. C. 2005. Soil Organic Matter. National Center fos Appropriate Technology. http://www.attra.ncat.org.

Bot, A. and J. Benites. 2005. The importance of soil organik matter Key to drought-resistant soil and sustained food production. FAO Soils Bulletin 80 . FAO of The United Nation. http://www.fao.org/docrep/009/a0100e/a0100e05.ht $\mathrm{m}$.

Brito, L., M., R. Pinto, I. Mourao, and J. Coutinho. 2012. Organic Lettuce, rye/vetch, and Swiss Chard Growth and Nutrient Uptake Response to Lime and Horse Manure Compost. Springer
Science+Business Media Dordrecht. DOI 10.1007/s13165-012-0032-9.

Burno, C. S. and J. K. Ladha. 2009. Comparison of Soil Properties between Continuously Cultivated and Adjacent Uncultivated Soils in Rice-based System. Springer-Verlag. DOI 10.1007/s00374009-0358-y.

Danuwikarsa, D., R. Robana, L. Irmawati, dan E. T. Susandi. 2012. Respons Tanaman Padi (Oryza sativa L.) terhadap Metode SRI dengan Berbagai Taraf Dosis Pupuk Organik dan Anorganik. Laporan Akhir Penelitian Unggulan PT. Uninus. Bandung.

Danuwikarsa, D., R. Robana, dan L. Irmawati. 2014. Respons Tanaman Padi (Oryza sativa L.) terhadap Metode SRI Semi Organik dengan Berbagai Sumber Pupuk Organik. Laporan Akhir Penelitian Unggulan PT. Uninus. Bandung.

Eikeren, N.van, H. de Boer, J. Bluem, T. Schouten, M. Rutgers, R. De Goede, and L. Brussaard. 2009. Soil Biological Quality of Grassland Fertilized with Adjusted Catle Manure Slurries in Comparison with Organic and Inorganik Fertilizers. Biololy and Fertility of Soils. Springer-Verlag. http://link.springer.com/article/10.1007/ s00374009-0370-2.

Gaspersz, V. 1995. Teknik Analisis Dalam Penelitian Percobaan. Tarsito. Bandung.

Horie, T., T. Shiraiwa, K. Katsura, Y. Maeda, and H. Yoshida. 2004. Can yields of lowland rice resumes the increases that showed in the 1980s/Paper on International Crop Science Congress. p.1-24.

Kaviraj and S. Sharma. 2003. Municipal Solid Waste Management Trought Vermicomposting Employing Exotic and Local Species of Earthworms. Bioresource Tecnology. 90: 169-173.

Lemanski, K. and S. Scheu. 2015. The Influence of Fertilizer Addition, Cutting Frequency and Herbicide Application on Soil Organism in Grassland. Biology and Fertility of Soils. Volume 51, Issue 2, pp 197-205. http://link.springer.com/article/ 10.1007/s00374014-0965-0.

Makarim, A.K. 2009. Aplikasi Ekofisiologi dalam Sistem Produksi Padi Berkelanjutan. Pusat Penelitian dan Pengembangan Tanaman Pangan. Pengembangan Inovasi Pertanian. 2(1), 2009: 1434.

Roubickova, A., O. Mudrak and J. Fruuz. 2009. Effect of Earthworm on Growth of Late Succession Plant Species in Postmining Sites under Laboratory and Field Condition. Biology and Fertility of Soils. Springer-Verlag. http://link.springer.com/article/ 10.1007/s00374-009-0356-7.

Suswana, S. and I. Danuwikarsa. 2014. Influence of Manure Proportion in Grow Media and Interval Water Supply on Growth of Jabon (Anthochepalus cadamba Roxb. Miq.) Seedling. International Journal of Basic and Applied Science. Insan 
Akademika Publications. Vo.03.No.2:154-168.

Suswana, S. dan C. Purwasih. 2015. Pengaruh Jenis dan Proporsi Pupuk Organik dalam Media Tumbuh Bibit dan Interval Penyiraman terhadap Pertumbuhan Bibit Gmelina (Gmelina arborea Roxb.). Laporan Hasil Penelitian (Tidak Dipublikasikan) Fakultas Pertanian Uninus. Bandung.
Swastika, D.K.S., J. Wargino, B. Sayaka, A. Agustian., V. Darwis. 2007. Kinerja dan Masa Depan Pembangunan Pertanian Tanaman Pangan. Prosiding: Kinerja dan Prospek Pembangunan Pertanian Indonesia. Pusat Analisis Sosial Ekonomi dan Kebijakan Pertanian. Badan Penelitian dan Pengembangan Pertanian. 